\title{
Genetic fingerprinting and phylogenetic diversity of Staphylococcus aureus isolates from Nigeria
}

\author{
Onasanya $A^{1,2 *}$, Mignouna H.D ${ }^{2, \alpha}$ and Thottappilly $G^{2, \wedge}$ \\ ${ }^{1}$ Department of Microbiology, Federal University of Technology Akure, Akure, Nigeria. \\ ${ }^{2}$ International Institute of Tropical Agriculture, PMB 5320, Ibadan, Nigeria.
}

Accepted 23 July 2003

\begin{abstract}
Genetic fingerprinting of 18 different isolates of Staphylococcus aureus from Nigeria using random amplified polymorphic DNA (RAPD) was carried out. Ten out of 100 Operon primers showed polymorphism among the isolates tested generating 88 bands, 51 of which were polymorphic with sizes ranging between 200 and 3,000 bp. All the isolates were classified completely into two major groups (Sa-1 and Sa-2) with twelve different subgroups. Sa-1 group originated from human while isolates from plant and animal origins formed the Sa-2 group. The twelve different subgroups suggest adaptation of $S$. aureus in the different host cells. This indicates possible relationship between host origin and genetic variation among $S$. aureus isolates. The DNA fingerprint defined for each race of $S$. aureus could be useful in epidemiological studies, medical diagnosis and the identification of new strains and their origins.
\end{abstract}

Keywords: Staphylococcus aureus, foodborne-acquired infections, genetic fingerprinting; phylogenetic diversity, RAPD, polymorphism.

\section{INTRODUCTION}

Staphylococcus aureus is one of the most common causes of foodborne-acquired infections, causing a wide variety of infections, from simple abscesses to fatal sephsis, as well as endocarditis, meningitis and toxinoses including food poisoning and toxic shock syndrome. Staphylococcus pathogenic versatility is compounded by its ability to develop resistance to new antibiotics almost as fast as they are introduced. However, nosocomial

*Corresponding author; Present address: West Africa Rice Development Association, BP 320, Bamako, Mali. Tel.: 223222 33 75. Fax: 22322286 83, E-mail address: a.onasanya@cgiar.org.

${ }^{\alpha}$ Present address: Virginia State University Agricultural Research Station Box 9061 Petersburg, VA 23806, USA.

'Present address: Mahyco Research Foundation, Kamalapuri colony, Hyderabad- 500073, India. infections caused by $S$. aureus are clinically serious and control of such infections requires strain typing to identify degree of virulence, the source of contamination, and resistance to commonly used antibiotics.

It is important in epidemiology and ecology to be able to identify bacterial species and strains accurately. Rapid identification and classification of bacteria is normally carried out by morphology, nutritional requirements, antibiotic resistance, isoenzyme comparisons, phage sensitivity (Eisenstein, 1990; Selander et al., 1987; Aber and Mackel, 1981; Milkman, 1973) and more recently by DNA based methods, particularly rRNA sequences (Woese, 1986), strain-specific fluorescent oligonucleotides (Delong et al., 1989; Amann et al., 1990) and the polymerase chain reaction (PCR) (Mullis and Faloona, 1987; Smith and Selander, 1990; McCabe, 1990).

Detection and identification methods using the PCR to amplify DNA have been used for other organisms (Hartskeerl et al., 1989), but these require sequence 
Table 1. Isolates of $S$. aureus used in this study.

\begin{tabular}{|c|c|c|c|c|}
\hline S/N & Isolate Code & Host & Source & Locality \\
\hline 1 & Sa01 & Pig & Pork & Ibadan \\
2 & Sa05 & Cow & Cooked meat & Ibadan \\
3 & Sa06 & Cow & Cooked meat & Kano \\
4 & Sa17 & Human & Stool & Ibadan \\
5 & Sa19 & Human & Stool & Ibadan \\
6 & Sa20 & Human & Stool & Ibadan \\
7 & Sa12 & Cow & Raw meat & Kano \\
8 & Sa13 & Cow & Raw meat & Ibadan \\
9 & Sa14 & Human & Urethra swab & Ibadan \\
10 & Sa25 & Human & Urethra swab & Ibadan \\
11 & Sa26 & Human & Urine & Ibadan \\
12 & Sa28 & Soya bean & Soya milk & Abuja \\
13 & Sa04 & Soya bean & Soya milk & Ibadan \\
14 & Sa07 & Soya bean & Soya milk & Ikenne \\
15 & Sa08 & Cow & Cow milk & Mokwa \\
16 & Sa33 & Commercial & Milk & Lagos \\
17 & Sa34 & Cow & Cow milk & Kano \\
18 & Sa41 & Human & Urine & Ibadan \\
\hline
\end{tabular}

information for specific primers. However, PCR using arbitrary primers (AP-PCR) requiring no prior sequence information has revealed DNA polymorphisms that may be useful for fingerprinting (Welsh and McClelland, 1990; Williams et al., 1990). Random amplified polymorphic DNA (RAPD) markers, which are based on the amplification of discrete DNA fragments in the genome by the use of oligonucleotide primers with random sequences, have been largely used to identify physiological races of fungi (Guthrie et al., 1992). With this technique a DNA fingerprint may define individual in a very fast and reliable way. RAPD-PCR method, when compared with biochemical methods is cheap, simple, more sensitive and faster. Apart from the study of antibiotic resistance (Ikeh, 2003), little is known concerning the genetic diversity that exists in populations of $S$. aureus isolates from human and food origins in Nigeria.

In this study genetic fingerprinting and phylogenetic diversity of isolates of $S$. aureus from Nigeria was evaluated using RAPD markers. Such information will be useful in its classification, epidemiological survey, ecology and diagnosis.

\section{MATERIALS AND METHODS}

\section{Genetic material}

S. aureus isolates (Table 1) used in this study were obtained from the University College Teaching Hospital, Ibadan, and the International Institute of Tropical Agriculture, Ibadan, Nigeria where their identity had been confirmed by coagulase biochemical test. Isolates preservation and storage were in accordance with Gore and Walsh (1964).

\section{Isolates propagation}

$S$. aureus isolates were first propagated using a modified procedure developed by Kado and Keskett (1970). About $200 \mu \mathrm{l} \mathrm{S}$. aureus isolate was transferred into $75 \mathrm{ml}$ of nutrient broth $(\mathrm{pH} 7.5)$ in a 250 $\mathrm{ml}$ conical flask and kept under constant shaking at $37^{\circ} \mathrm{C}$ for $24 \mathrm{~h}$. The bacterial cell was removed by centrifugation, washed with 0.1 $\mathrm{mM}$ Tris-EDTA and kept at $-20^{\circ} \mathrm{C}$ for DNA extraction.

\section{Genomic DNA Extraction}

DNA extraction was according to Roeder and Broda (1987) and Thottappilly et al. (1999) with some modification. $0.3 \mathrm{~g}$ of washed bacterial cell were suspended in $200 \mu \mathrm{l}$ of 2 xCTAB buffer $(50 \mathrm{mM}$ Tris, $\quad \mathrm{pH} \quad 8.0 ; 0.7 \quad \mathrm{mM} \quad \mathrm{NaCl} ; \quad 10 \quad \mathrm{mM} \quad$ EDTA; 2\% hexadecyltrimethylammonium bromide; $0.1 \%$ 2-mercaptoethanol), followed by the addition of $100 \mu \mathrm{l}$ of $20 \%$ sodium dodecyl sulfate and incubated at $65^{\circ} \mathrm{C}$ for $20 \mathrm{~min}$. DNA was purified by two extractions with phenol:chloroform:isoamyl alcohol (24:25:1) and precipitated with $-20^{\circ} \mathrm{C}$ absolute ethanol. After washing with $70 \%$ ethanol, the DNA was dried and resuspended in $200 \mu \mathrm{l}$ of sterile distilled water. DNA concentration was measured using DU-65UV spectrophotometer (Beckman Instruments Inc., Fullerto CA, USA) at $260 \mathrm{~nm}$. DNA degradation was checked by electrophoresis on a $1 \%$ agarose gel in 1xTAE (45 mM Tris-acetate, $1 \mathrm{mM}$ EDTA, $\mathrm{pH}$ 8.0).

\section{RAPD-PCR analysis}

RAPD-PCR analysis was according to Guthrie et al. (1992). DNA primers tested were purchased from Operon Technologies (Alameda, California, USA) and each is 10 nucleotides long. Two concentrations of each DNA (24ng and $96 \mathrm{ng}$ per reaction) were used to test reproducibility and eliminate sporadic amplification products from the analysis. One hundred primers (OPA, OPY, OPA, OPX and OPW series) were screened with two isolates (Sa01 and Sa14) for their ability to amplify the $S$. aureus DNA. Ten of these 
primers (Table 2) were found useful since they gave polymorphism. These were used in amplifying the DNA from all $S$. aureus isolates. Amplifications were performed in $25 \mu$ reaction mixture consisting of genomic DNA, 1X reaction buffer (Promega), $100 \mu \mathrm{M}$ each of dATP, dCTP, dGTP, and dTTP, $0.2 \mu \mathrm{M}$ Operon random primer, 2.5 $\mu \mathrm{M} \mathrm{MgCl} 2$ and $1 \mathrm{U}$ of Taq polymerase (Boehringer, Germany). A single primer was used in each reaction. The reaction mixture was overlaid with $50 \mu \mathrm{l}$ of mineral oil to prevent evaporation. Amplification was performed in a thermowell microtiter plate (Costa Corporation) using a Perkin Elmer programmable Thermal Controller model 9600 . The cycling program was (i) 1 cycle of $94^{\circ} \mathrm{C}$ for $3 \mathrm{~min}$; (ii) 45 cycles of $94^{\circ} \mathrm{C}$ for $1 \mathrm{~min}$ for denaturation, $40^{\circ} \mathrm{C}$ for 1 min for annealing of primer and $72^{\circ} \mathrm{C}$ for 2 min for extension; and (iii) a final extension at $72^{\circ} \mathrm{C}$ for $7 \mathrm{~min}$. The amplification products were resolved by electrophoresis in a $1.4 \%$ agarose gel using TAE buffer (45 mM Tris-acetate, $1 \mathrm{mM}$ EDTA, $\mathrm{pH} 8.0$ ) at $100 \mathrm{~V}$ for $2 \mathrm{~h}$. A $1 \mathrm{~kb}$ ladder (Life Technologies, Gaithersburg, MD, USA) was included as molecular size marker. Gels were visualized by staining with ethidium bromide solution $(0.5 \mu \mathrm{g} / \mathrm{ml})$ and banding patterns were photographed over UV light using a red filter.

Table 2. Oligonucleotide primers that showed genetic discrimination among the $S$. aureus isolates using RAPD-PCR analysis.

\begin{tabular}{|c|c|c|c|}
\hline $\begin{array}{c}\text { Operon } \\
\text { code }\end{array}$ & $\begin{array}{c}\text { Nucleotide sequence } \\
\text { 5' to 3' }^{\prime}\end{array}$ & $\begin{array}{c}\text { No of } \\
\text { fragments } \\
\text { amplified }\end{array}$ & $\begin{array}{c}\text { No of } \\
\text { polymorphic } \\
\text { bands }\end{array}$ \\
\hline OPX-04 & CCGCTACCGA & 12 & 6 \\
OPX-12 & TCGCCAGCCA & 14 & 9 \\
OPX-17 & GACACGGACC & 15 & 9 \\
OPX-20 & CCCAGCTAGA & 7 & 5 \\
OPY-01 & GGTGGCATCT & 8 & 3 \\
OPY-07 & CTGGACGTCA & 5 & 3 \\
OPY-09 & GTGACCGAGT & 7 & 5 \\
OPY-10 & TCGCATCCCT & 6 & 2 \\
OPY-11 & CTGATGCGTG & 6 & 3 \\
OPY-13 & CACAGCGACA & 8 & 6 \\
& Total & 88 & 51 \\
\hline
\end{tabular}

\section{Phylogenetic analysis}

Positions of unequivocally scorable RAPD bands were transformed into a binary character matrix (" 1 " for the presence and " 0 " for the absence of a band at a particular position). Pairwise distance matrices were compiled by the NTSYS-pc 2.0 software (Rohlf, 1993) using the Jaccard coefficient of similarity (Jaccard, 1908). Phylogenetic tree was created by the unweighted pair-group method arithmetic (UPGMA) average cluster analysis (Sneath and Sokal, 1973; Swofford and Olsen, 1990).

\section{RESULTS AND DISCUSSION}

Ten primers showed polymorphisms among individuals isolates out of 100 primers tested. The amplification reactions with the 10 primers generated 88 bands, 51 of them being polymorphic (Table 2) with sizes ranging between 200 and 3,000 base pairs (Figure 1). Using 51 RAPD markers to construct phylogenetic relationship among $18 \mathrm{~S}$. aureus isolates led to classification into two major groups (Sa-1 and Sa-2) at 50\% similarity coefficient while twelve different subgroups were obtained at $100 \%$ similarity coefficient (Figure 2 ).

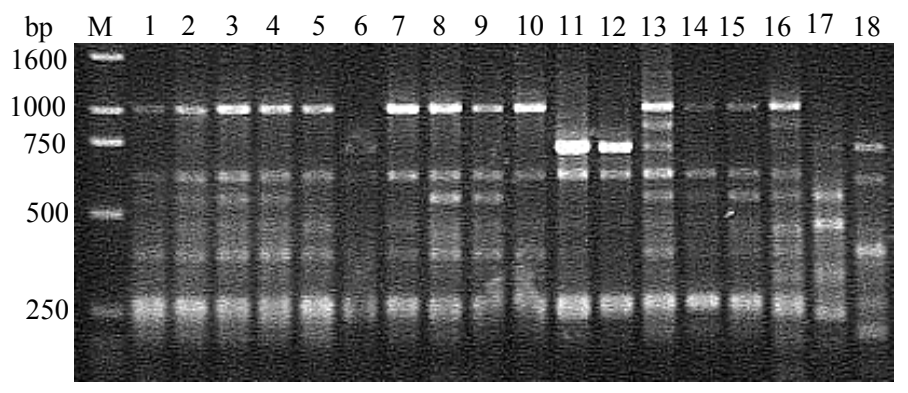

Figure 1. DNA fingerprinting patterns of $18 \mathrm{~S}$. aureus isolates using OPX-12 RAPD primer. M: $1 \mathrm{~kb}$ molecular size marker.

Genetic fingerprinting and phylogenetic diversity between different $S$. aureus isolates were determined by converting RAPD data into a Jaccard similarity matrix and analysed by UPGMA to produce a phylogenetic tree. The DNA band pattern obtained is similar to a bar code, allowing the identification of each individual. For instance, isolate $\mathrm{Sa04}$ presents unique bands when its DNA amplified with most of the primers tested (Figure 1). These bands could be used to characterize and identify it. All the isolates were classified completely into two major groups (Sa-1 and Sa-2) with twelve subgroups. Sa1 group comprised of isolates originated from human while isolates from plant and animal origins formed the Sa-2 group. However, the twelve different subgroups obtained in this study suggests possible and frequent occurrence of mutants in S. aureus in different host cells.

Historically, S. aureus has been described as a variable bacterium with many pathogenic and antibiotic resistance variants (Coltman, 1979; Kloos and Schleifer, 1981). The limited number of morphological and cultural characters of $S$. aureus, and the lack of standardization of cultural conditions and virulence tests among different researchers have led to confusion and uncertainty in the characterization of this pathogen (Kloos and Schleifer, 1981). Distinct phenotypes usually consist of isolates that are genetically less related and such identification of isolates using biochemical, cultural and morphological techniques often lack consistency and precision (Kloos and Schleifer, 1981). In the current study, we have found that identification of genetic diversity in $S$. aureus depends on sources of isolates, different host cells and occurrence of mutants. For instance, seven isolates genotyped as Sa-1 were originated from human while 


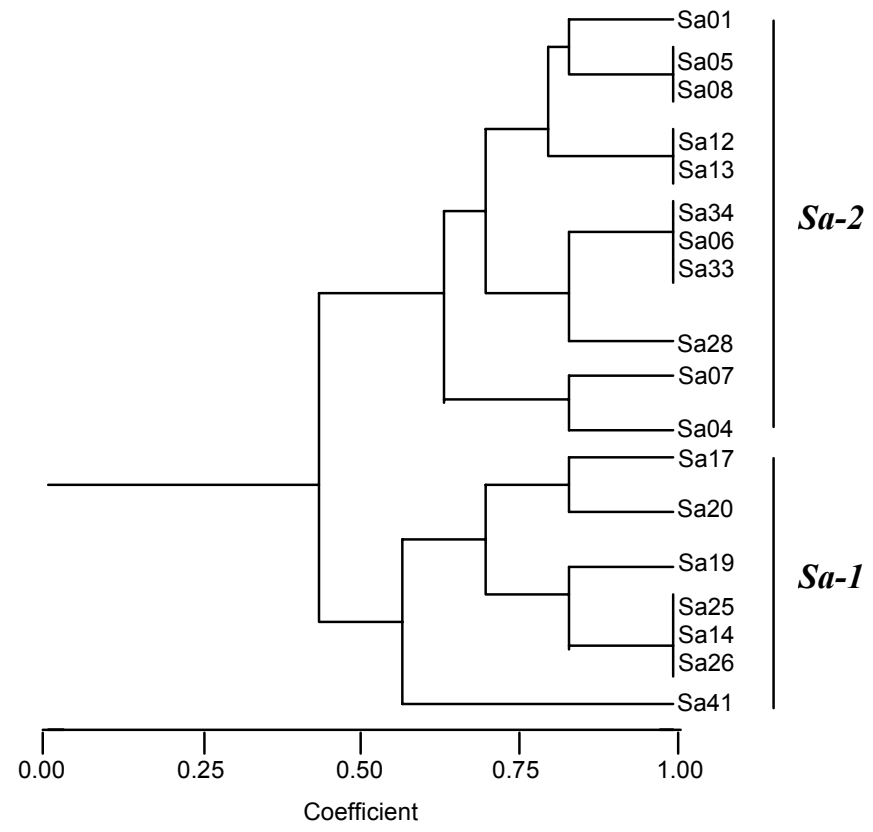

Figure 2. Phylogenetic diversity of $18 \mathrm{~S}$. aureus isolates identified by 51 RAPD markers.

three and eight isolates respectively from plant and animal origins were genotyped as Sa-2 (Figure 2). Besides, the possible and frequent occurrence of mutants in $S$. aureus constitutes the broad genetic variation that exists within Sa-1 and Sa-2 genotypes.

RAPD markers revealed possible relationship between host origin, mutation and genetic variation among $S$. aureus isolates, and this demonstrated its fingerprinting and diagnostic potential. Obviously, for these DNA bands patterns to have a practical meaning in the areas of medicine, population biology and epidemiology, specific DNA bands must be related to host origins, mutation and virulence genes (Welsh and McClelland, 1990). This could be accomplished by a systematic comparison of DNA band patterns among bacteria contrasting for the different host origins, mutation and virulence genes present. Similar approach has been used to differentiate aggressive from non-aggressive isolates of the oilseed rape pathogen Phoma lingam (Schafer and Wostmeyer, 1992).

The DNA fingerprint defined for each race of $S$. aureus should be useful for epidemiological surveys, medical diagnoses, and in the identification of new virulent strains and isolates and their origin.

\section{ACKNOWLEDGEMENT}

We thank the International Institute of Tropical Agriculture, Ibadan, Nigeria, for sponsoring this project.

\section{REFERENCES}

Aber RC, Mackel DC (1981). Epidemiological typing of nosocomial microorganisms. Am. J. Med. 70: 899-905.

Amann RI, Krumholz L, Stahl DA (1990). Fluorescent-oligonucleotide probing of whole cells for determinative, phylogenetic, and environmental studies in microbiology. J. Bacteriol. 172: 762-770.

Coltman K (1979). Urinary tract infections: New thoughts on an old subject. Practioner 223: 351-355.

Delong EF, Wickham GS, Pace NR (1989). Phylogenetic stains: ribosomal RNA-based probes for the identification of single cells. Science 243: 1360-1363.

Eisenstein BI (1990). New molecular techniques for microbial epidemiology and the diagnosis of infectious diseases. J. Infect. Dis. $160: 595-602$

Gore LF, Walsh P (1964). Preservation and storage of bacterial cultures. J. Med. Lab. Technol. 21: 244-246.

Guthrie PAI, Magill CW, Frederiksen RA, Odvody GN (1992). Random amplified polymorphic DNA markers: a system for identifying and differentiating isolates of Colletotrichum graminicola. Phytopathology 82: 832-835.

Hartskeerl RA, De Wit MYL, Klatser PR (1989). Polymerase chain reaction for the detection of Mycobacterium leprae. J. Gen. Microbiol. 135: 2357-2364.

Ikeh El (2003). Methicilin-resistant Staphylococcus aureus (MRSA) at Jos University Teaching Hospital. Afr. J. Clin. Expt. Microbiol. 4 (1) : 48-52.

Jaccard, P (1908). Nouvelles recherches sur la distribution florale. Bull. Soc. Vaudoise Sci. Nat. 44 : 223-270.

Kado Cl, Keskett MG (1970). Selective media for isolation of Agrobacterium, Corynebacterium, Erwinia, Pseudomonas, Xanthomonas. Phytopathology 60: 969-976.

Kloos WE, Schleifer KH (1981). The genus staphylococcus in the prokaryotes: A handbook on habitat, isolation and identification of bacteria. Vols. 1 and 2.

McCabe PC (1990). PCR Protocols: a guide to methods and applications. Academic Press. 76-83 pp.

Milkman R (1973). Electrophoretic variation in Escherichia coli from 
natural sources. Science 182: 1024-1026.

Mullis KB, Faloona FA (1987). Specific synthesis of DNA in vitro via a polymerase-catalyzed chain reaction. Method Enzymol. 155: 335350.

Roeder V, Broda P (1987). Rapid preparation of DNA from filamentous fungi. L. Appl. Microbiol. 1: 17-20.

Rohlf FJ (1993). NTSYS-pc. Numerical Taxonomy and Multivariate Analysis system. Exeter, New York.

Schafer E, Wostmeyer J (1992). Random primer dependent PCR differentiates aggressive and non-aggressive isolates of the oilseed rape pathogen Phoma lingam (Leptosphaeria maculans). J. Phytopathol. 136: 124-136.

Selander RK, Caugant DA, Whittam TS (1987). Escherichia coli and Salmonella typhimurium. Cellular and Mol. Biology. Neidhardt F.C. (Ed. In Chief) ASM, pp. 1625-1648.

Smith NH, Selander RK (1990). Sequence invariance of the Antigencoding central region of the phase 1 flagellar filament gene (fliC) among strains of Salmonella typhimurium. J. Bacteriol. 172: 603609.
Sneath PHA, Sokal RR (1973). The principle and practice of numerical classification. In: Kennedy, D., Park, R.B. (Eds.), Numerical Taxonomy. Freeman, San Francisco.

Swofford DL, Olsen GJ (1990). Phylogenetic reconstruction. In: Molecular systematics. Hillis D.M. and Moritz C. (eds). Sinauer Associates, Sunderland, 411-501 pp.

Thottappilly G, Mignouna HD, Onasanya A, Abang M, Oyelakin O, Singh NK (1999). Identification and differentiation of isolates of Colletotrichum gloeosporioides from yam by random amplified polymorphic DNA markers. Afr. Crop Sci. J. 7 (2): 195-205.

Welsh J, McClelland M (1990). Fingerprinting genomes using PCR with arbitrary primers. Nucleic Acids Res. 24: 7213-7218.

Williams JGK, Kubelik AR, Livak KJ, Rafalski JA, Tingey SV (1990). DNA polymorphism amplified by arbitrary primers are useful as genetic markers. Nucleic Acids Res. 18: 6531-6535.

Woese CR (1986). Evolution in Prokaryotes. Schdleifer K.H. and Stackebrandt E. (eds). Academic Press, London. 